\title{
Morphometric Analysis of Digaru River Basin, Lohit District, Arunachal Pradesh
}

\author{
Rinkiolu Chai \\ Research Scholar, Rajiv Gandhi University, Rono Hills Itanagar
}

\begin{abstract}
Rivers are the dynamic process which tends to change the channel morphology and hydrological characteristics by the process of erosion and deposition. Drainage basin as a whole or its sub-basins is considered one of the most fundamental geomorphic units. So the study of various properties of rivers and drainage basins is quite pertinent. Such a study is useful in ascertaining the stages of geomorphic evolution of different basins, topographic characteristics, and hydrological conditions of the concerned area which inturn will provide necessary input for catchment management strategies.

The Digaru River is an alluvial river which itself is dynamic system that adjust their geometry according to differential rates of stream flow (discharge) and sediment load. This research work tries to deal with the theoretical view on geomorphic basin and changes that is going on by quantitatively analysing the morphometric characteristics, because the existing geological and geomorphological informations on Lohit district are not adequate for evolving a valid and acceptable model for the geomorphic evolution of the catchment.
\end{abstract}

Key words: Fundamental, Digaru, Geomorphic, Pertinent, Topographic, Catchment, Morphometric, Adequate, Discharge, Quantitatively, Theoretical, Discharge.

\section{Introduction}

Fluvial geomorphology is one of the important components of geomorphology, which deals with the evolution, structure, function and dynamics of the river system and which provides an understanding of the process of water and sediment in river catchments and channels and their floodplains together with the forms produced by those processes. It can be called as an interdisciplinary science which attempts to understand the processes and process-form relationships of a river system.

According to the source Resource Atlas by Savindra Singh (1999), the Lohit Himalaya is absence of Gondwana and Siwalik rocks and existence of a zone of ultrabasic and granodiorite associated with metasediments. In the vast varried terrain of the study area with numerous rivers, it is difficult to provide any generalization about the type of soils, the granite and geneise formation interspersed with calcareous limestone and slate and other minerals tempered largely by swift flowing hilly rivers, it is found that the region is endowed with four types of soil formation viz Alluvium, Older Alluvium, Buxa formation and Bomdila, Tenga and Miri formatiopn. Due to heterogenity of the basic rocks and sedimentary formation of soils, there is great variation in the nature and composition of the soils and also the loose and fragile surface matter, undulating topography, steep valley slopes, river terraces, juvenile river systems, humid tropical and sub-tropical climatic conditions are responsible for the existing morphological characteristics of the basin. The region lies in the Vth seismic zone and reported techtonically very active. All the above mentioned characteristics designate the region as of geoenvironmentally having a unique set up.

\section{Statement of the problem}

The study area falls under a very strategic location i.e Tidding thrust in the northern side and Mishmi thrust in the southern side that makes the region geologically very fragile. According to the source Singh and Choudhary (1990), the rocks of Mishmi group of hills are exposed over large part of the Lohit district in the eastern Himalaya. In this region all litho-units are trending NW-SE and dippind towards NE. It includes Metasediments and associated granite genesis, granodiorite and granite with mafic and ultramafic intrusive. These existing lithounits has a great impact on the land and peopling in the surrounding of the basin area in their mode of peopling, socio-economic development, pattern of human settlement, agricultural pattern etc.

The Digaru River is an alluvial river which originates from the south-eastern slope of the Mishmi hills of Lohit district at a height of 3785m above MSL (Mean Sea Level) and flows over the unstable formation of the hilly tract with dynamic systems that is drained by numbers of intermontane river system with potential to bring about rapid changes in the landscapes. The major hazards related to this region are flood, landslides, bankerosion and channel course shifting. Some of which are frequently recurrent and some are continuous. The cause for these may be due to the clilmatic conditions and more of less due to the basin physiography of the region. This river flows with high turbulent velocity during rainy season carrying sand and debris. Bank erosion and 
landslides are common phenomena of this region due to its meandering course and due to the loose and sandy soil types.

Since the region is geologically very fragile, the runoff water comes into river with heavy silt and debris with turbulent flow, as a result river looks muddy and water level of the river bed use to raised up (mostly during monsoon) and flattened causing severe inundation to the nearby areas, having its negative impact on the socio-economic condition of the region. Due to steep gradient in the upper part of the study area, the velocity of the river flow use to be very high during summer, which causes heavy erosion to the bank at various locations leading to broadning of channel, thereby threatening the very existence of the government and public properties, road communication, agricultural land, settlement areas etc. Numbers of the agricultural plots use to face loss of soil/natural fertile soil due to the erosion in the surrounding of the study area. These scenarios are very common and use to occur almost every year, posing a serious threat to the general ecology and environment of the region. In this regard we can talk about the most destructive events of the study area in a chronological manner to highlight the importance of the study. The 1988 flood in the Digaru and its nearby areas, which was due to the continuous rain, wherein the whole region was inundated by the flood water of the Digaru and its intermontane streams causing damages to the anthropogenic factors of the region. The 2004 flash flood of Tebang Nallah, which was originally known as Sukha Nallah was a small gully, collecting rain water from the nearby catchment area of upper Loiliang village but during the flash flood of 2004, the course of Tebang Nallah (one of the tributary stream of Digaru river) has got diverted into it and thereby causing flood hazard to Danglat village. The 2012 flood, which is most recent devastating flood, reflects the continuous environmental impacts on the inhabitants of the region which was also due to the continuous rain and thereby causing the shifting of the course of the channel, posing serious threat to the ecological balance of the region.

\section{Study area}

Location: The study lies in the district of Lohit, northeastern extrimity of Arunachal Pradesh, India situated between the $27^{\circ} 50^{\prime} 05^{\prime \prime} \mathrm{N} \& 28^{\circ} 13^{\prime} 10^{\prime \prime} \mathrm{N}$ Latitudes and $96^{\circ} 00^{\prime} 20^{\prime \prime} \mathrm{E} \& 96^{\circ} 15^{\prime} 40^{\prime \prime}$ E Longitudes, with an areal extension of about 529.22 sq.km. The total length of the basin from its head to the point of its confluence with Lohit river is 50.8 meter. Though the Digaru basin covers a small area in context of the whole district i.e 11,402 sq. $\mathrm{km}$ (according to census report 2001), it is characterised by complex and intricate drainage system. The typical features exhibited are believed to have been produces by the interactions of the underlying folded structures, varied geomorphological processes speciallyt the rocks of Mishmi groups are exposed over large part of the district in the eastern Himalaya and all the litho units are trending NW-SE and dipping towards NE, according to the source (Singh and Choudhary,1990). Demography: The district is populated by 77,315 (male) and 66213 (female) with a total population of about 1,43,527 persons contributing 13 persons per sq.km to the total density of the country (according to 2001 census report). The sex ratio i.e number of females per thousand males is 856 and literacy rate 56.05 percent. The populatiopn is almost rural, inhabiting some 524 villages, with major tribes like Mishmi, Khampti and other indigennouis groups like Meyors/Zakhning, Singphos, and Padams. In recent past the Tibetian, Chakma and Hazong refugees have been settled here. There are various other group of people who also live and are engaged with government services, constructional work and in business.

\section{Aim of the Study}

The main aim of the research is to give an interpretative account of the development of fluvial landforms and drainage pattern as the underlying structure and technics under the multiple cycles of fluvial erosion. Further, to specify the relief and slope characteristics of the watershed area.

\section{Data base and Methodology}

The present study has been done based on both primary and secondary data sources. For the study of Digaru river basin, the entire work has been carried out based on the topographical map bearing sheet no. 90 D/4 on the scale of 1:50,000 of Survey of India and the geological maps of the district is drawn from the work carried out by earlier workers.

Morphometric techniques have been implemented to understand the morphometric character of the region. The methodology for the morphometric analysis is based on method suggested by Horton's and Strahler's for the stream ordering, relationship between stream density and frequency. Cartographic and statistical methods are used to carry out slope analysis and to evaluate the mapping and relationship analysis.

The weather or climatic data like rainfall, temperature and humidity data collected are collected from Indian Meteorological Department, Directorate of Economics and Statistics, District Statistical Handbook. The analysis of the structural conditions, stratigraphic set up, morphology of the study area is being done by preparing slope and relief map. The drainage map of the study area has been drawn with the help of 1:50,000 topographical sheets published by the Survey of India. The number of confluences, number of streams, length 
of streams etc. have been counted on the drainage map and shown in separate maps using the choropleth and isopleths techniques. The stream line surface map has also been prepared, which indicates the amount of denudation of the landsurface. The stream line surface has been obtained by plotting intersections of actual contours and main stream.

Finally, the GIS techniques has been used to draw base map, contour map, relief map, slope map and drainage map with the help of segment, point and polygon method.

\section{Relief Analysis}

Relief can be analysed in terms of absolute and relative or local elevation. The knowledge of relief and forms is essential for understanding the spatial arrangement of landforms, which facilitates a better placing and more rational use of particular area.

For the interpretation of relief and topography of Digaru basin the contour pattern provides significant information for the investigation.

\section{Relative relief}

Relative relief also termed as 'amplitude of available relief or local relief', is defined as the difference in height between the heighest height and the lowest height in a unit area, it may be grid, square, rectangle or a minute-grid square. Relative relief is a very important morphometric variable which is used for the overall assessment of morphological characteristics of terrain and degree of dissection. It denotes actual variations of height in a unit area with respect to its base level. The relative relief map of the area expresses the amount of slope and nature of surface slope.

Following the Smith's method of slope analysis (1935) the relative relief of Digaru basin has been determined and mapped. The choropleth and isopleth techniques have been used to depict the nature of surface slope per unit area and the trend of the slope respectively. For the study of spatial variation, relative relief in each grid square is calculated on the basis of the highest and lowest elevations and the data of relative relief so derived are tabulated and classified into categories viz. i) extremely low relative relief, ii) moderately low relative relief, iii) low relative relief, iv) moderate relative relief, v) moderately high relative relief and vi) high relative relief. With the help of the isopleth techniques i.e, isolines the different relief classes have been prepared and shaded (fig 3.1). The table no. 3.1 reveals all the representation of areal distribution of each category.

Table- 1 Showing Distribution of Relative Relief in Digaru River Basin

\begin{tabular}{|l|r|r|l|}
\hline \multicolumn{1}{|c|}{ Relief Categories } & Area (in sq km) & Area (in \%) & \multicolumn{1}{c|}{ Categories } \\
\hline$<300 \mathrm{~m}$ & 48.35 & 16.08 & Very low relative relief \\
\hline $300 \mathrm{~m}-500 \mathrm{~m}$ & 89.12 & 30.22 & Low relative relief \\
\hline $500 \mathrm{~m}-700 \mathrm{~m}$ & 98.12 & 33.55 & Moderate relative relief \\
\hline $700 \mathrm{~m}-900 \mathrm{~m}$ & 50.79 & 17.06 & High relative relief \\
\hline$>900 \mathrm{~m}$ & 8.962 & 3.1 & Very high relative relief \\
\hline Total & 288.28 & 100 & \\
\hline
\end{tabular}




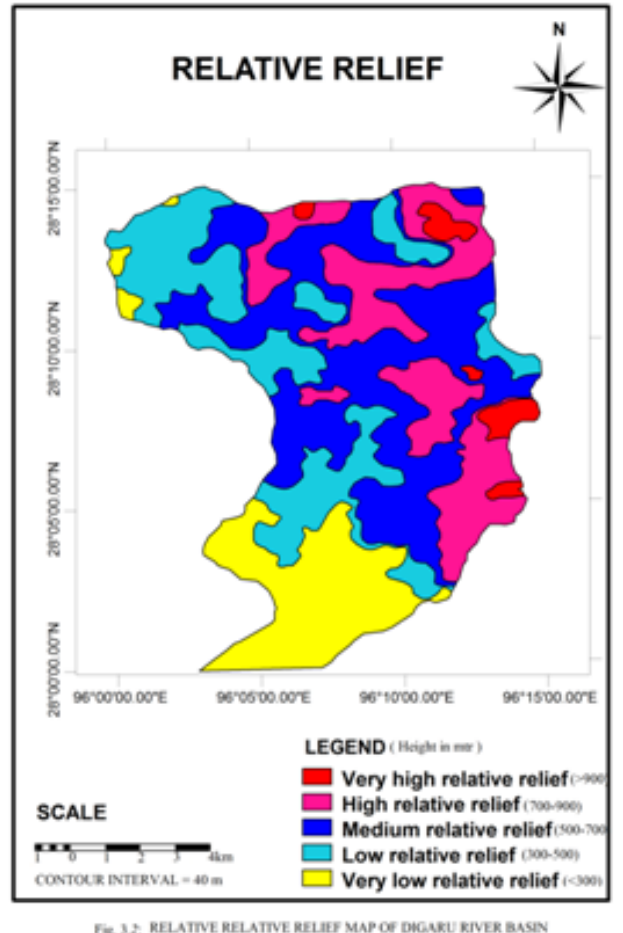

\subsection{Very low relative relief $(<300 \mathrm{~m})$}

The first category i.e., below $300 \mathrm{~m}$ is termed as the very low relative relief of the area. It accounts for $16.08 \%$ of the basin, covering an area of about $48.35 \mathrm{sq} \mathrm{km}$. This category is concentrated in the southern and scattered in the north western portion of the basin. It shows that this category is having very less or no degree of dissection and lies in the river valley plains region, where the height is not more than $300 \mathrm{~m}$.

\subsection{Low relative relief $(300 \mathrm{~m}-500 \mathrm{~m})$}

This category is scattered in the basin and is found in the southern and western portion of the basin. It accounts for $30.22 \%$ of the basin covering an area of about $89.12 \mathrm{sq} \mathrm{km}$, having less degree of dissection, since the degree of dissection depends upon the altitude of the region.

\subsection{Moderate relative relief $(500 \mathrm{~m}-700 \mathrm{~m})$}

It spreads over $98.12 \mathrm{sq} \mathrm{km}$ and covers an area of about $33.55 \%$ of the total basin area. This group accounts the maximum area among the categories and is concentrated in the central portion of the basin, where we found the degree of dissection is high.

\subsection{High relative relief $(700 \mathrm{~m}-900 \mathrm{~m})$}

This category spreads over $50.79 \mathrm{sq} \mathrm{km}$ and covers an area of about $17.06 \%$. It ranges from 700-900 $\mathrm{m}$. The concentration is found in both the upper part and eastern portion of the basin.

\subsection{Very high relative relief $(>900 \mathrm{~m})$}

This category i.e., above $900 \mathrm{~m}$ is termed as the very high relative relief of the area. It accounts for 3.1 $\%$ of the basin and is found in the northern and eastern portion of the basin. The region is having the maximum degree of dissection.

\section{Absolute Relief}

Absolute relief means the highest height in a unit area. In the present study, for the delineation of an absolute relief map, the whole study area has been divided into grids of $2 \times 2 \mathrm{~km}^{2}$ each and the highest point falling over each unit has been recorded and placed accordingly. The resulted absolute height has been divided into five categories and shown in a map using isopleth and choropleth technique (fig.3.2). The table below shows the areal expansion of each category- 
Table- 2 Showing Absolute Relief of Digaru River Basin

\begin{tabular}{|l|l|l|l|}
\hline Height (in m) & Area (in sq. Km) & Area (in \%) & Category \\
\hline$<1000$ & 54.49 & 18.98 & Very low absolute relief \\
\hline $1000-1500$ & 46.19 & 16.09 & Low absolute relief \\
\hline $1500-2000$ & 62.72 & 21.85 & Moderate absolute relief \\
\hline $2000-2500$ & 64.52 & 22.48 & High absolute relief \\
\hline$>2500$ & 58.96 & 20.54 & Very high absolute relief \\
\hline
\end{tabular}

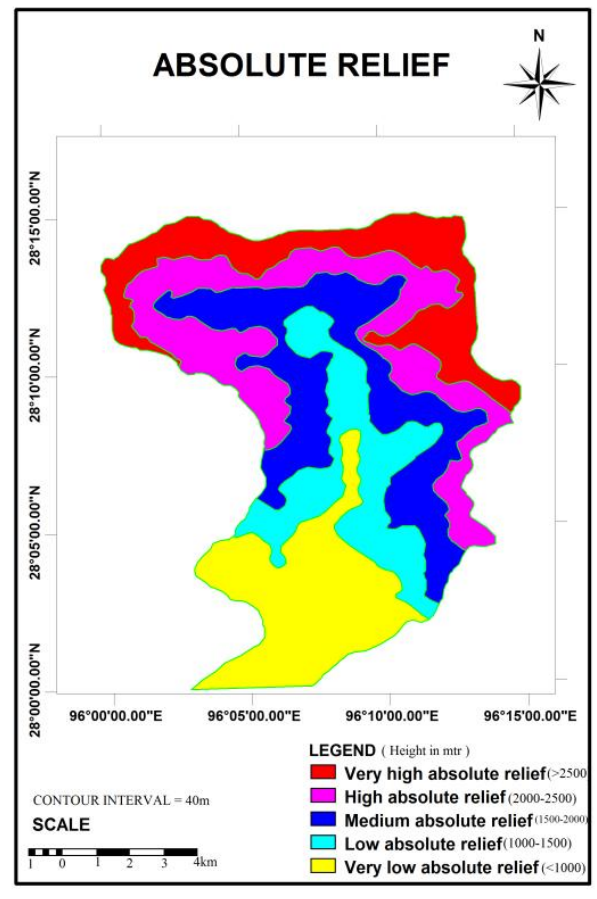

Fig. 3.3: ABSOLUTE RELIEF MAP OF DIGARU RIVER BASIN

\subsection{Very low absolute relief $(<1000 \mathrm{~m})$}

The lower height group i.e., below 1000 accounts for about $18.98 \%$, covering an area of $54.49 \mathrm{sq} \mathrm{km}$ of the total basin area. It is confined in the southern portion of the basin.

\subsection{Low absolute relief $(1000 \mathrm{~m}-1500 \mathrm{~m})$}

This category lies in the central portion of the basin area, covering about $46.19 \mathrm{sq} \mathrm{km}$ of area and 16.09 $\%$ of the total basin area.

\subsection{Moderate absolute relief $(1500 \mathrm{~m}-2000 \mathrm{~m})$}

The zone between 1500-2000 $\mathrm{m}$ height is termed as moderate absolute relief. It covers an area of about $62.72 \mathrm{sq} \mathrm{km}$, covering $21.85 \%$ of the total basin area. It lies in the central portion of the study area.

\subsection{High absolute relief $(2000 \mathrm{~m}-2500 \mathrm{~m})$}

Ranging between the height of $2000 \mathrm{~m}-2500 \mathrm{~m}$ above mean sea level, the region is termed as high absolute relief. It is concentrated in the northern and central portion of the basin, covering an area of about 64.52 sq $\mathrm{km}$ and accounting $22.48 \%$ of the total basin area.

\subsection{Very high absolute relief $(>2500 \mathrm{~m})$}

This group is concentrated in the northern portion of the basin, covering an area of $58.96 \mathrm{sq} . \mathrm{Km}$, which accounts $20.54 \%$ of the total basin area.

\section{Altitudinal Zone}

Altitudinal zone reflects the height of the region. The altitudinal zone map of the Digaru basin is shown in fig. 3.3 and the tabular form of categorization is shown in table no.3.3 below- 
Table- 3 Showing Altitudinal Zone of Digaru River Basin

\begin{tabular}{|l|l|l|l|}
\hline Height in m & Area in sq km & Area in \% & Category \\
\hline$<400$ & 23.13 & 8.02 & Very low altitudinal zone \\
\hline $400-1000$ & 60.02 & 20.83 & Low altitudinal zone \\
\hline $1000-1600$ & 76.69 & 26.62 & Moderate altitudinal zone \\
\hline $1600-2200$ & 65.72 & 22.81 & High altitudinal zone \\
\hline$>2200$ & 62.49 & 21.69 & Very high altitudinal zone \\
\hline
\end{tabular}

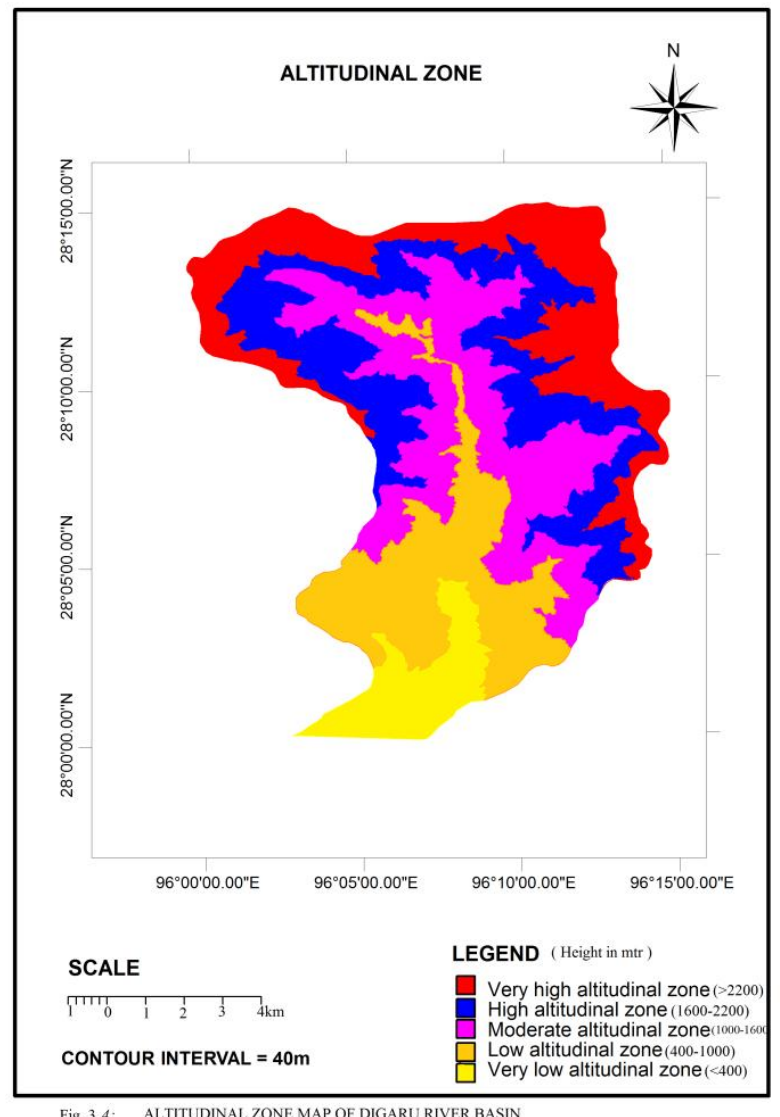

Fig. 3.4: ALTITUDINAL ZONE MAP OF DIGARU RIVER BASIN

\subsection{Very low altitudinal zone $(<400)$}

The zone accounting height below $400 \mathrm{~m}$ is termed as very low altitudinal zone. It lies in the southern portion of the basin, covering an total area of about $8.02 \%$, spreading over $23.13 \mathrm{sq} \mathrm{km}$.

\subsection{Low altitudinal zone $(400 \mathrm{~m}-1000 \mathrm{~m})$}

The zone ranging between $400-1000 \mathrm{~m}$ is termed as low altitudinal zone. It lies in the southern central portion of the basin, accounting an area of about $60.02 \mathrm{sq} \mathrm{km}$, covering $20.83 \%$ of the total basin area.

\subsection{Moderate altitudinal zone $(1000 \mathrm{~m}-1600 \mathrm{~m})$}

Covering an area of about $76.69 \mathrm{sq} \mathrm{km}$, the region is termed as moderate altitudinal zone, which lies in the central portion of the basin area, accounting an area of about $26.62 \%$.

\subsection{High altitudinal zone $(1600 \mathrm{~m}-2200 \mathrm{~m})$}

The zone ranging between 1600-2200 m height above mean sea level accounts an area of about 65.72 sq $\mathrm{km}$, covering $22.81 \%$ area of the total basin area.

\subsection{Very high altitudinal zone $(>2200 \mathrm{~m})$}

With a height more than $2200 \mathrm{~m}$ constitute $62.49 \mathrm{sq} \mathrm{km}$ with $21.69 \%$ of the total area of the region is termed as very high altitudinal zone. It is concentrated in the northern portion of the basin.

\section{Profile Analysis}

A profile on the relief features is a visual aid in its description and interpretation. Hence, it is of particular interest for geomorphologist. Broadly speaking, a profile means an outline of the relief (elevation) or depression (along a selected line), for example, the profile of a river valley. Since the cantoned maps, which is 
an indispensable and tob geomorphologist is incomplete in its indication (Wooldridge and Morgan, 1946), the terrain provides a better knowledge of the absolute relief. Serial, superimposed, projected and composed profiles are frequently used in the geomorphological interpretation of the terrain as they are very useful in depicting the nature of the general relief and different surface. In the study area, these p[rofiles shows the visual pictures of the surface configuration.

Generally, the profiles are of two types i.e.,

1. River profile

River profile is further sub-divided into two:

i) Longitudinal profile

ii) Transverse profile

2. Terrain profile

Terrain profile is further sub-divided into four

i) Serial profile

ii) Superimposed profile

iii) Projected profile

iv) Composite profile.

\section{Serial profile}

Serial profile is drawn along east and west direction (fig.5). The diversification of undulating, topography is being marked by serial profiles. The eroded, dissected and characteristics of the terrain observed near the excavated river valley areas. In profile drawing it becomes very necessary to exaggerate the vertical scale in order to give prominence to the relief features, which would otherwise remain unrecognised. This exaggeration of vertical scale should not be too much that the desirable amount of exaggeration and however it depend upon map scale and relative altitude of the region.

For the study area five serial profiles are prepared by taking the traverse from east to west outline of the basin. All these profiles drawn separately have been arranged in a column representing a series from one end of the map to other in a single frame i.e., watershed boundary.

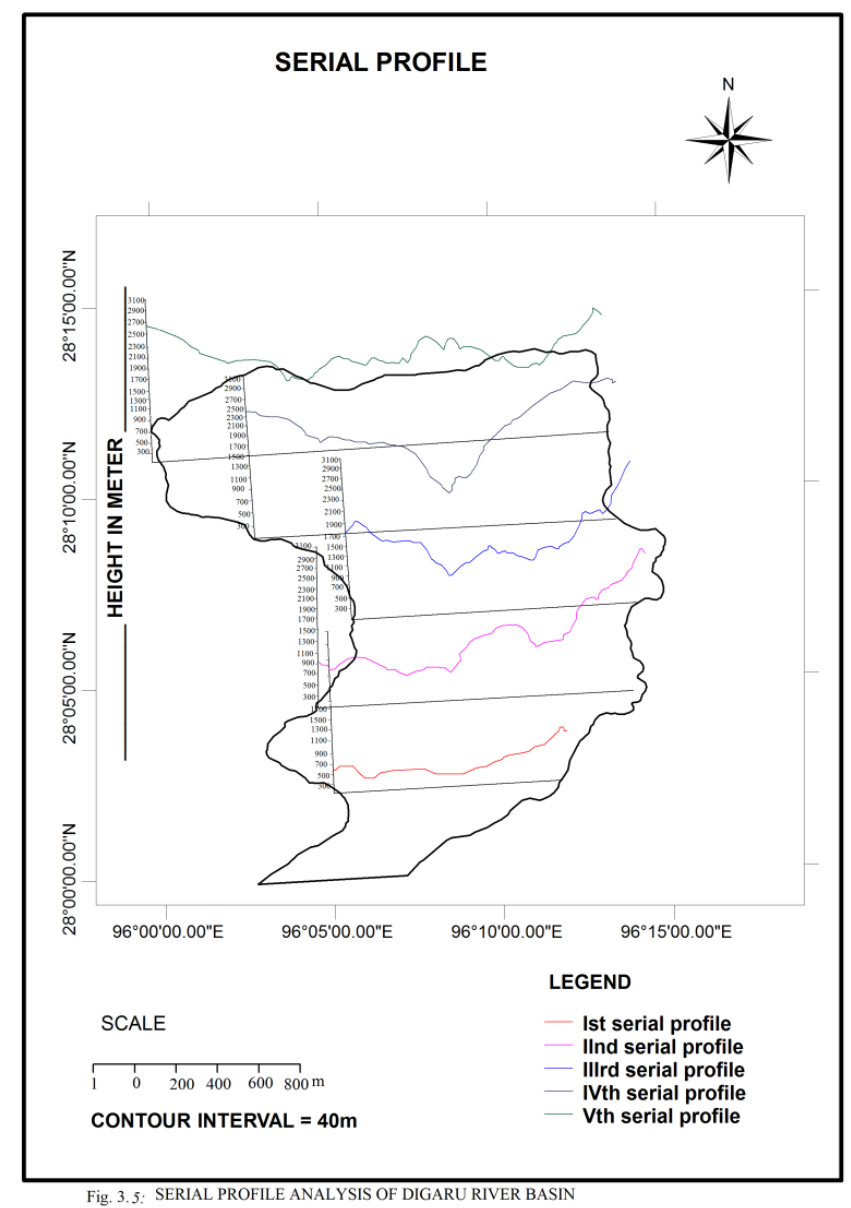




\section{Superimposed profile}

Superimposed profile determines the different levels of planation surfaces. For the construction of the vary profile all the prepared serial profiles are traced in a single frame, and the skyline of each profile is being drawn by using different colour or different lines. The superimposed profile of Digaru river basin is shown in the figure below-

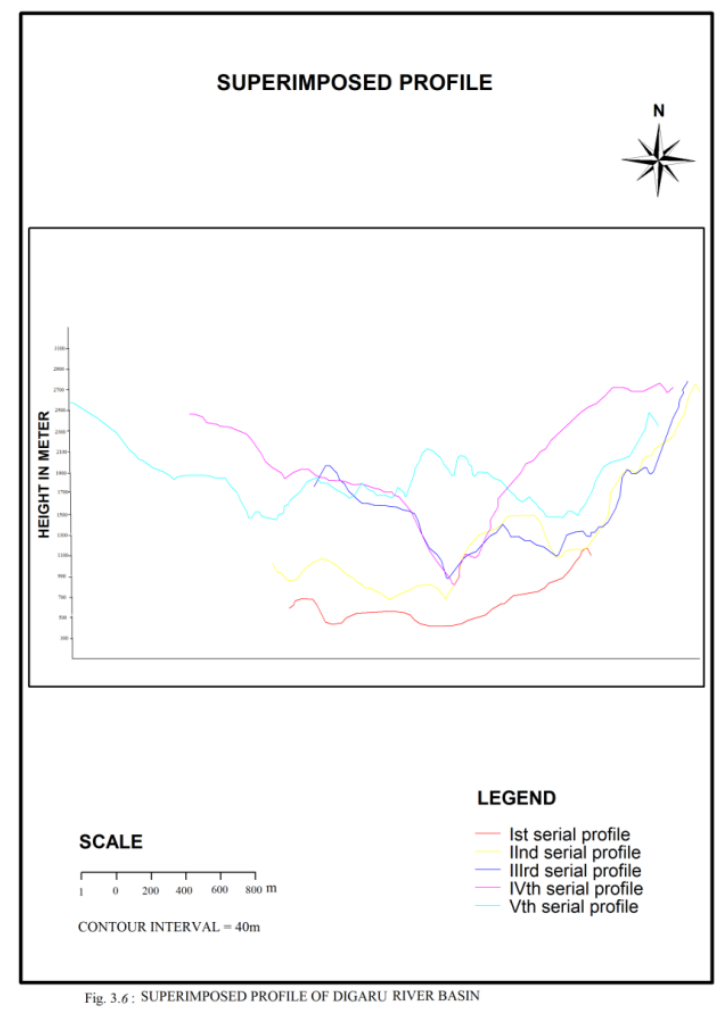

\section{Projected profile}

It is a careful imposition of a series of profile over other but is slightly different from superimposed profile. In this case too, all the serial profiles are traced in a single frame but the difference is that in this profile the portion of profiles that comes below the succeeding one is left untraced unlike superimposed profile. A projected profile shows only those features that are not observed by higher intervening form. Hence, it is better to begin with the end of series where the profile depicts an area of comparatively higher absolute relief than that of the other end of the series. Projected profiles give a panoramic effect with a foreground and distant skyline, as shown in the figure below- 


\section{Composite profile}

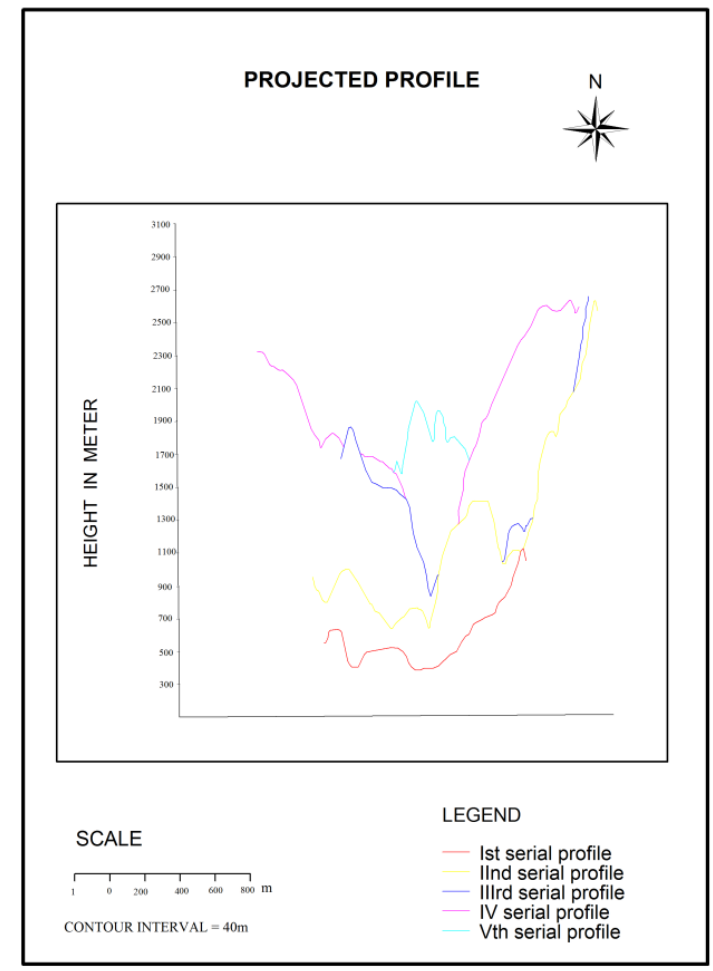

Fig. 3.7: PROJECTED PROFILE OF DIGARU RIVER BASIN

A composite profile shows only the ruggedness of the skyline, as shown in the figure below. It is constructed to represent the surface as viewed in the horizontal plain of the submit level from an infinite distance, it form a diagram of superimposed profiles as projected profiles only. The upper most line is traced on a similar frame of the same size that represent composite profile of the study area.

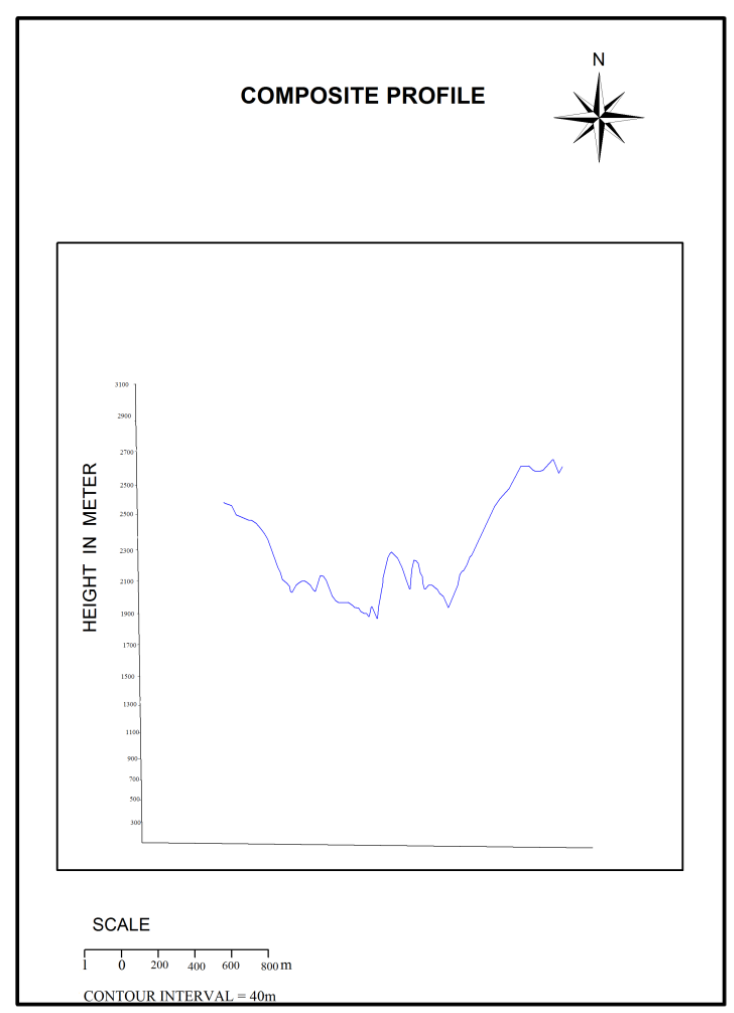

Fig 3.8. COMPOSITE PROFILE OF DIGARU RIVER BASIN 


\section{Hypsometric Curve}

Hypsometric curve is generally used to show the proportion of an area of the surface at various elevations above or below or datum (F.G. Morkhove and H.R. Wilkinson, 1967).

It refers to the distribution of elevation as a function of area occupied by each contour interval within a geometric unit. It is the study of the distribution of horizontal cross sectional area of a landmass with respect to elevation. It is used to differentiate between erosional landmass at different stages during their evolution. The basic data requires for its preparation are area between successive contours and their respective height. The hypsometric curve is an important tool for the analysing of landform evolution over the geologic time scales. The shape of the hypsometric curve shows the age of the particular catchment. The tabular form of hypsometric curve analysis of Digaru basin is given in the table below-

Table- 4 Showing Hypsometric Analysis of Digaru River Basin

\begin{tabular}{|l|l|l|}
\hline Height (in m) & Total area & Cumulative area (in \%) \\
\hline$>2200$ & 62.49 & 288.06 \\
\hline $1600-2200$ & 65.72 & 225.57 \\
\hline $1000-1600$ & 76.69 & 159.84 \\
\hline $400-1000$ & 60.02 & 83.15 \\
\hline$<400$ & 23.13 & 23.13 \\
\hline
\end{tabular}

Hypsometric curve of Digaru river basin

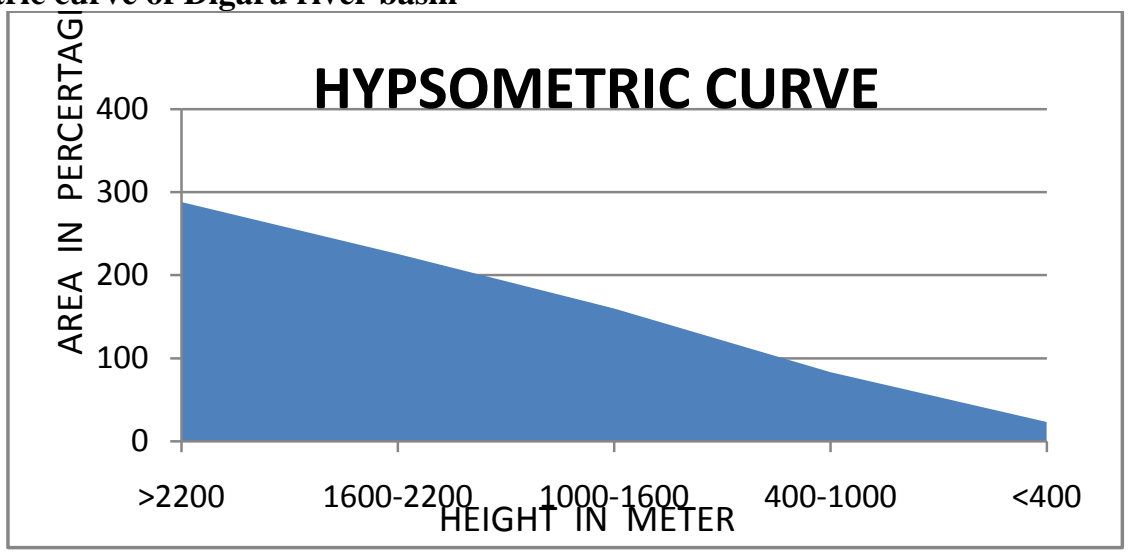

Result Derived:

The area enclosed under different contour of Digaru river basin with meters contour intervals have been computed with the help of the percentage of the area of each categories are computed and their cumulative frequency has been drawn. The percentage of area and the height of contour are marked on vertical and horizontal lines respectively. Joining the coordinate points, hypsometric curve has been drawn. From the study it is found that the region is still in the young age and here the denudational process is not very high.

\section{Altimetric Frequency Curve}

Altimetric frequency curve involves the computations of frequency of occurrence of heights above sea levels and plotting it on graph paper. Either spot heights all over the map of an area may be counted, on the map be covered up a grid of small squares and the highest point in each square be noted. The precision of altimetric analysis largely depends on the nature of contour maps. Altimetric analysis helps in identifying and determining the erosion surface. Percentage of the frequency should be graphed along the vertical scale and the actual elevations along the horizontal scale.

The altimetry frequency graph of the Digaru basin is shows that maximum frequency is under 1600 meter height, as shown in the table below-

Table- 5 Showing Altimetric Frequency Graph of Digaru River Basin

\begin{tabular}{|l|l|}
\hline ALTITUDINAL ZONE(m) & AREA (in $\mathbf{~ k m}^{2}$ ) \\
\hline$<400$ & 23.13 \\
\hline $400-1000$ & 60.026 \\
\hline $1000-1600$ & 76.691 \\
\hline $1600-2200$ & 65.726 \\
\hline$>2200$ & 62.493 \\
\hline
\end{tabular}




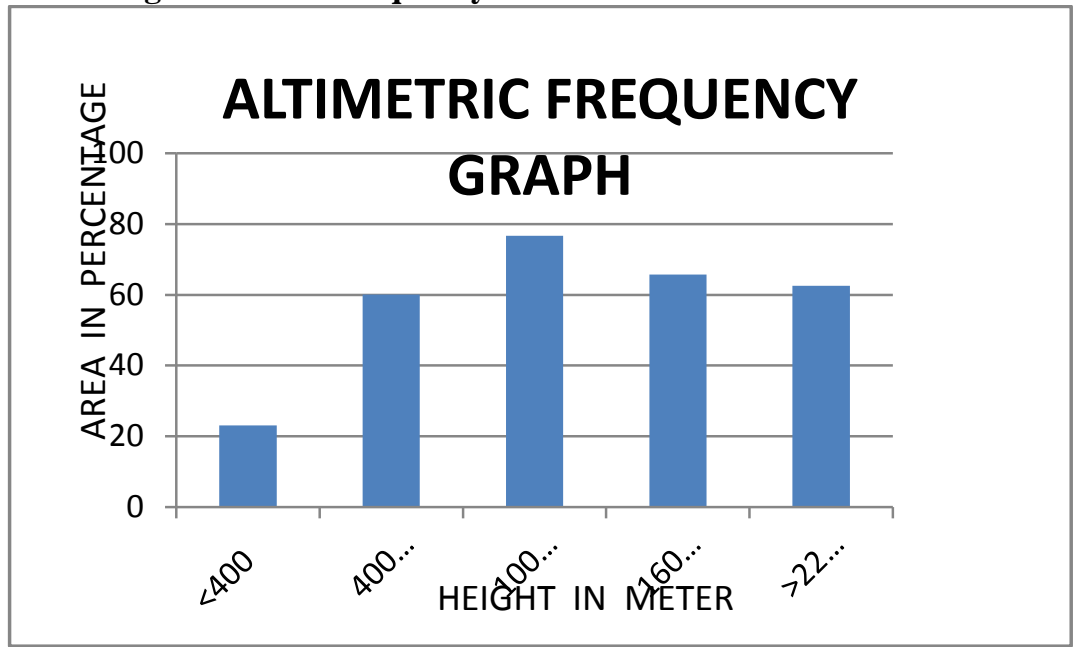

\section{Result Derived:}

From the prepared histogram of the altimetric frequency, it can be take out that the region which lies in the higher altitude has less erosion in compare to the low lying or river valley area.

\section{Slope Analysis}

Computation of slope angles from topographical maps or through field measurement involves tedious and time consuming procedures. Several techniques of the derivation and computation of average slopes from topographical maps have been suggested from time to time e.g., J L Rich (1916), C K Wentworth (1930), G H Smith ( 1938,1939), E Raize and J Henry (1937), W C Calef (1950), W C Calef and R New Comb (1953), A N Strahler (1956) etc., but the techniques of Wentworth being easier and involving lesser measurement and calculation and more rapid procedure than other schemes has been widely used by several geomorphologists.

\section{Average Slope}

Slope simply means an angular inclinations of terrain between hill-tops and valley bottoms, resulting from the combination of many causative factors like geological structure, absolute and relative reliefs, climate, vegetation cover, drainage texture and frequency, dissection index etc.

Computation of slope angles from topographical sheets and maps is very tedious and time consuming procedure. Several techniques have been suggested through time e.g. G.H. Smith (1938,1939), J.L. Rich (1916) and many more but the scheme suggested by C.K. Wentworth (1930) has got its wide acceptance in the geomorphological studies because of ite easier and involving less measurement and calculation than other scheme.

For the preparation of the average slope map, the study area be divided into $2 \times 2 \mathrm{~cm}$ grids, each having straight lines at right angles and the number of contour crossings along the edges of grid are counted and then the average number of contour crossings is computed.

By using the following formula, as suggested by Wentworth, tan values are derived and actual slope angles resulting from tan values are obtained from log table.

Slope in degree $=\tan \Theta=\mathrm{N} / 4 \times$ C.I $/ 636.6$

Where, N/4 = average no. of contour crossing

$\mathrm{N}=$ No. of contour crossing

C.I $=$ Contour interval

$636.6=$ constant value

The table below represents the average slope of the Digaru river basin:

Table- 6 Showing Average Slope of Digaru River Basin

\begin{tabular}{|l|l|l|l|}
\hline Height (in m) & Area (in sq $\mathbf{~ k m})$ & Area (in \%) & Slope categories \\
\hline$<20$ & 44.76 & 15.27 & Very low average slope \\
\hline $20-27$ & 14.06 & 4.56 & Low average slope \\
\hline $27-34$ & 110.75 & 39.55 & Moderate average slope \\
\hline $34-41$ & 90.45 & 38.83 & High average slope \\
\hline$>41$ & 26.86 & 31.94 & Very high average slope \\
\hline
\end{tabular}




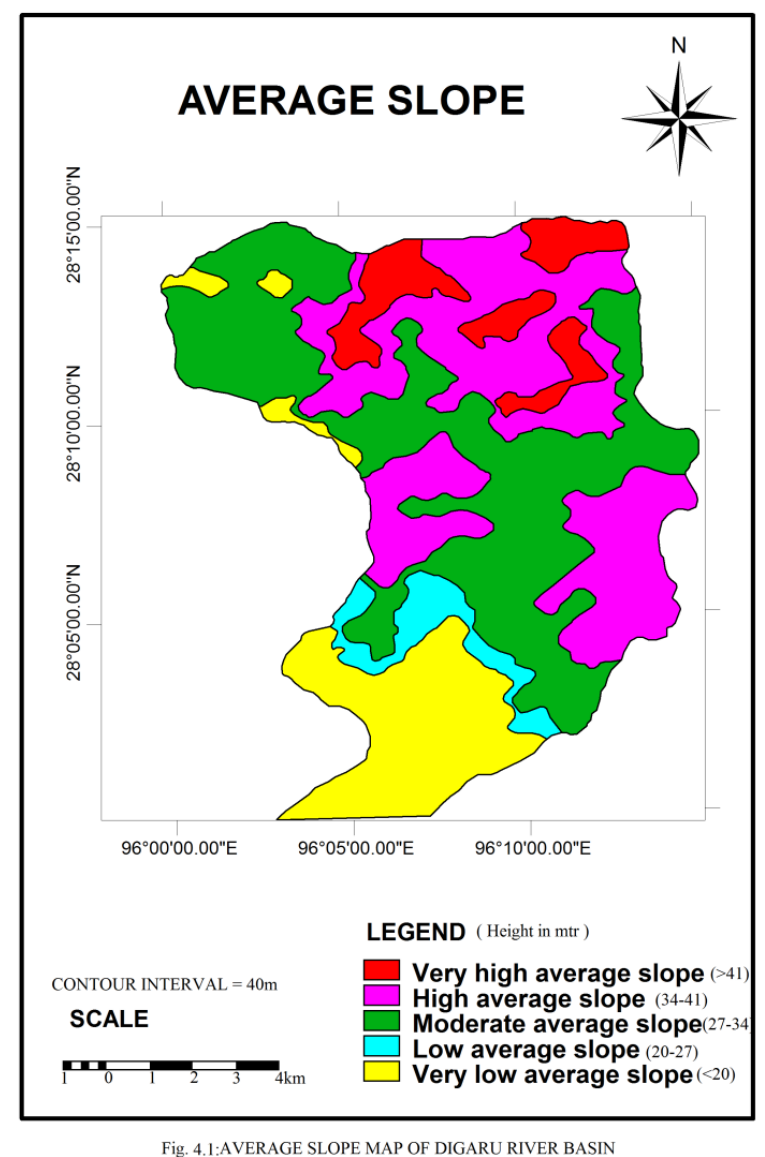

\subsection{Very low average slope}

A very low average slope covers an area of 44.76 sq.km from the total area, which constitude $15.27 \%$ of the total basin area. This category of slope is found near the valley region. Lithologically, this area might be of less resistant rock and fertile soil that has had a very low average slope. This area are suitable of agriculture. Sunpura, $19^{\text {th }}$ Mile, $20^{\text {th }}$ Mile (chailiang), Hatiduba, Paya, Haju Khuti camp falls under this category.

\subsection{Low average slope}

It covers an area of 14.06 sq. $\mathrm{Km}$, constituting $4.56 \%$ area of the total area. The category is found in the southern portion of the basin area, which is also having less resistant rock fertile soil and moisture condition of soil leads to good agricultural productivity. The villages like SSB camp, $27^{\text {th }}$ Mile, Jhalukbari, Danglat falls under this category.

\subsection{Moderate average slope}

This very group covers an area of 110.756 sq. Km, which constitude $39.55 \%$ area of the total area. This category is spread over whole the northern, central, eastern and western portion of the basin. The village which comes under this category are Bhekuliang, Mekeliang, Loiliang, Lohitpur.

\subsection{High average slope}

High average slope region covers an area of about 90.45 sq. Km, constituting $38.83 \%$ area of the total area $(288.28$ sq. $\mathrm{Km})$. The region lies in the central and northern portion of the basin area. It has resistant rock strata, which create hindrance in the agricultural activity, but in some area shifting cultivation is being practiced.

\subsection{Very high average slope}

A very high average slope region covers an area of 26.86 sq. $\mathrm{Km}$, constituting $31.94 \%$ area of the total basin area. This category of slope is found near the source region i.e., Mishmi Hills. Lithologically, this area 
might be of more or very high resistant rock that has had a steep landform. These areas are covered with dense vegetation and not suitable for agriculture.

\section{Drainage Analysis:}

The Digaru river is the master stream of the Digaru drainage basin. It has a number of sub- tributaries such as the Haju river, Denning Nala, Tabang Nala etc. The Digaru, its main tributaries and sub-tributaries, the rivulets and rills constitude the Digaru river system, which contributes their water in the mighty Lohit river. The part of the land surface, the rain water of which is drained out by the Digaru river system, may be called the Digaru catchment or drainage basin. The main drainage axis of the Digaru river runs in NE-SW directions. The Digaru river originates from Mishmi hills, with its right and left bank tributaries, flows first in the hilly terrain upto village Bhekuliang, where it debouches onto Digaru valley. On emerging over the plain, the river looses much of its energy and its whole character changed. It begins to flow in a zigzag course forming many meanders, parallel streams.

This drainage basin has an area of 287.871 sq. $\mathrm{Km}$ and the length of the stream from source to the mouth is $35.25 \mathrm{~km}$. It is an Vth order river, the table below will show the number, length and stream ordering.

Table- 7 Showing Number, Length \& Stream Ordering

\begin{tabular}{|l|l|l|}
\hline Stream Order & No. of Stream & Stream Length (in km) \\
\hline Ist & 710 & 9.83 \\
\hline IInd & 51 & 2.62 \\
\hline IIIrd & 42 & 1.01 \\
\hline Ivth & 8 & 0.69 \\
\hline Vth & 1 & 0.66 \\
\hline
\end{tabular}

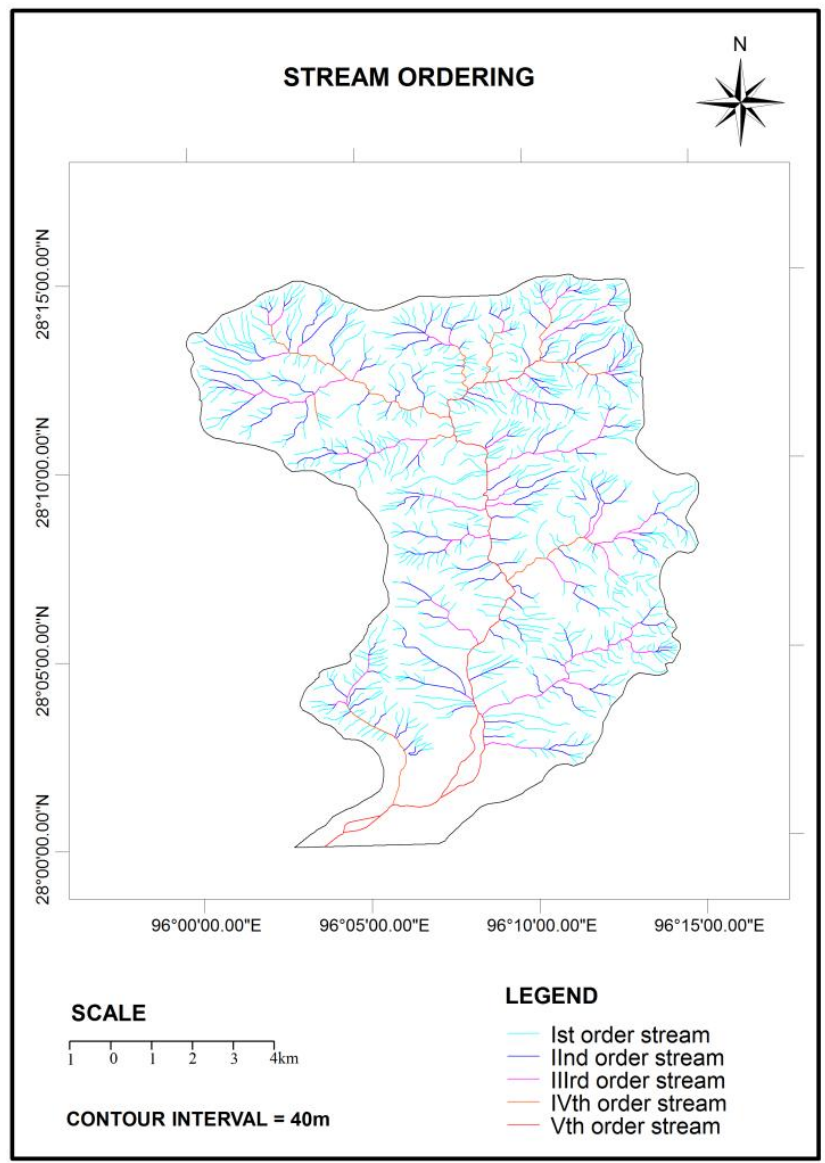

Fig.5.2: STREAM ORDERING MAP OF DIGARU RIVER BASIN

\section{Drainage Pattern}

The design or form of drainage system in terms of geometrical shapes in the areas of different rock types and their structure, that emerges on a drainage map on account of the assemblage of drainage channels is called drainage pattern. 
The study of drainage pattern is very important and useful in geomorphic analysis, since it reflect the influence of initial slope, resistivity to erosion of rocks, structural control, recent geologic and geomorphic history of the drainage basin. Because drainage patterns are influenced by so many factors, they are extreamly helpful in the interpretation of geomorphic features and the study of them represents one of the more practical approaches to an understanding of structural and lithologic control of landform evolution ( Thornbury, 1985). Therefore, the detailed study of the drainage pattern of the Digaru basin is taken up to evaluate its geomorphic features and its structural and lithologic controls.

The drainage pattern that emerged after study are like- parallel pattern, dendritic pattern, rectangular pattern, radial pattern and trellis pattern.

\section{Parallel pattern}

Parallel pattern develops only in a region where there are parallel weaker plane i.e., joints, faults, contact zone of two lithology, thrust. This pattern consists of parallel master and tributary streams. This pattern develops where there is a strong structural control in one direction for e.g. where strata are generally dipping. This type of pattern is found in the middle portion of north eastern part of the Digaru basin.

\subsubsection{Dendritic pattern}

The most common drainage pattern found in the area is the dendritic pattern. It resembles the tree like shape and consists of a single main stream (trunk) with tributaries (branches of the tree). Dendritic pattern shows homogeneity in lithology and structure. In the study area it is found that the pattern is spread all over the basin mostly in the extream north, northeartern and northwestern portion.

\subsubsection{Rectangular pattern}

The rectangular pattern is found in the central portion of the basin and in this type, the tributary stream meet with principal stream forming right angle because it is formed by the two sets of joints in a weaker plane.

\subsection{Trellis pattern}

The network of tributaries and master consequent streams forms trellised drainage patterns. They develop in the area of simple folds characterised by parallel anticlinal ridges alternated by parallel synclinal valleys. In the present study this type of drainage pattern is found in the south eastern side of the basin.

\subsubsection{Radial pattern}

It is a type of drainage pattern develops when streams flow outwards from a central dome shape mountain or upland. Schumm (1973) reflects that "this type of drainage system pattern develops on flanks of domes and volcanoes where there is no effect of differing rock resistance". In this present study, this type is found in the north western portion of the basin. 


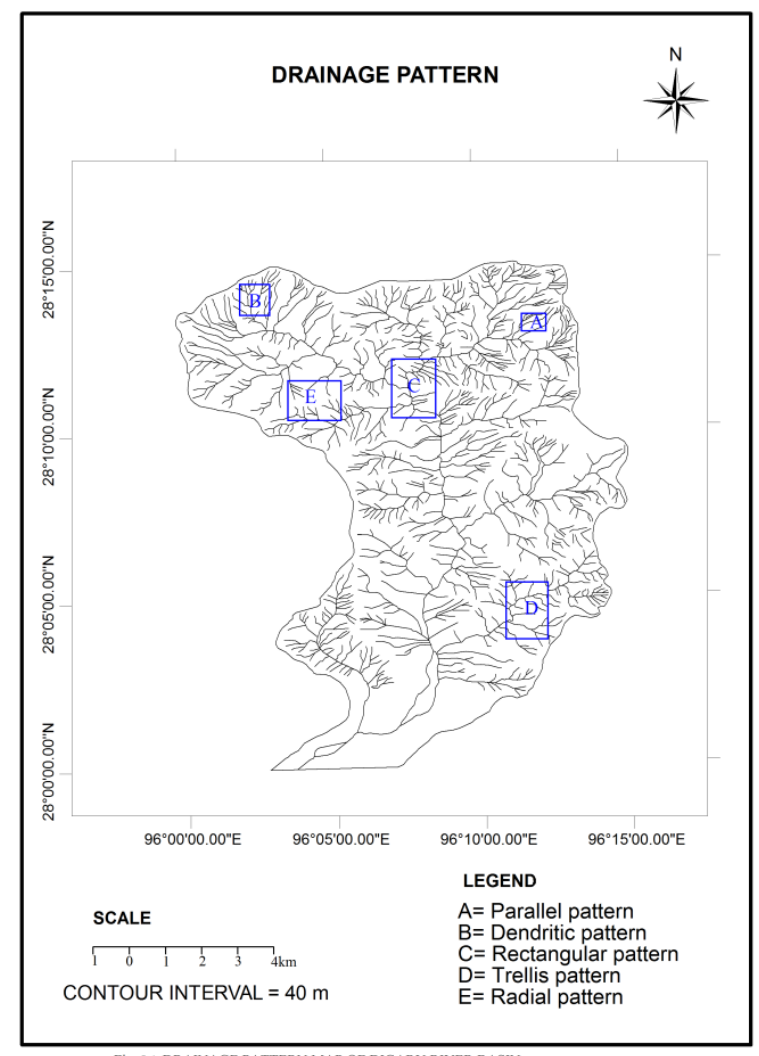

\section{Stream Ordering}

The stream ordering was first proposed by R E Horton (1945), which led to the development of certain laws of drainage composition. According to him, the two streams of first order, when joins together forms IInd order just below their junction. Similarly, two IInd order meet to form the IIIrd order stream nd the process continues till the trunk stream is given the highest order. Subsequently, Strahler (1964) modified the Horton's scheme of stream ordering by removing the problem of reclassification and renumbering of streams. The scheme of A. N. Strahler is thus considered as the most simplest and easy for application and it has been extensively used by the geomorphologist for the morphometric analysis of network. Thus, in the present case too, A.N.Strahler's scheme has been adopted to carry out the same. The selected drainage basin is having the highest range upto Vth order shows the vastness of the basin area.

\section{Bifurcation Ratio (Rb)}

Bifurcation ratio was introduced by Horton (1932), to express the ratio of the number of streams of any given order to the number in the next order. It shows the degree of integration prevailing between streams of various orders in a drainage basin.

It can be calculate by using the formula :

$$
\mathrm{Rb}=\mathrm{Nu} / \mathrm{Nu}+1
$$

higher order.

Where, $\mathrm{Nu}=$ no. of streams of a given order $\mathrm{Nu}+1=$ no. of streams of the next

Table- 5.2 Showing Stream Order, Number \& Bifurcation ratio

\begin{tabular}{|l|l|l|}
\hline $\begin{array}{l}\text { Stream Order } \\
(\mathbf{u})\end{array}$ & Number of Streams & Bifurcation Ratio \\
\hline Ist & 710 & - \\
\hline IInd & 51 & 13.92 \\
\hline IIIrd & 42 & 1.21 \\
\hline Ivth & 8 & 5.25 \\
\hline Vth & 1 & 8 \\
\hline
\end{tabular}

Bifurcation ratio, a dimensionless property of the drainage basin is supposed to be controlled by drainage density, stream entrance angles (junction angles), lithological characteristics, basin shapes, basin areas etc. Usually the range varies in between 3 to 5 for network of streams formed in homogeneous rock. But in the present case it got exceed from 1.21 to 13.92 , which reflect that the region has pronounced structural control that 
encourages the development of elongated narrow drainage basin. Low value shows the higher degree of integration ( Sarbesh Singh and M.K.Singh,1997).

\section{Geometry of Basin Shape}

The geometry of the baisn shape is of paramount significance as it helps in the description and comparison of different forms of the drainage basins and it is also related to the functioning of the units of the basins and its genesis. Various methods have been suggested to calculate the shape of the basins.

\subsubsection{Horton's Form Factor (F),1932}

$\mathrm{F}=\mathrm{A} / \mathrm{L}^{2}$

Where, $\mathrm{F}=$ Form Factor indicating elongation of basin shape.

$\mathrm{A}=$ Basin area

$\mathrm{L}=$ Basin length

$$
\begin{gathered}
\text { Given, } \mathrm{A}=287.871 \\
\mathrm{~L}^{2}=35.25^{2}=1242.562 \\
\text { Therefore, } \mathrm{F}=287.87 \\
=0.231
\end{gathered}
$$

5.5.2 V.C. Miller's Circularity Index (c), 1953

$\mathrm{C}=$ Area of the basin/ Area of the circle with same perimeter as the basin

$$
\mathrm{C}=4 \Pi \mathrm{A} / \mathrm{P}^{2}
$$

Or

Therefore, $\mathrm{C}=4 \times 22 / 7 \times 287.871 /(161.5)^{2}$

$$
\begin{aligned}
& =4 \times 904.737 / 26082.25 \\
& =3618.949 / 26082.25 \\
& =0.13875
\end{aligned}
$$

\section{Result Derived:}

Therefore, from the above calculation, we have found that the present drainage basin is of elongated shape, as the $\mathrm{F}$ value varies from 0-1. So it can be called that Digaru river basin is of elongated or highly elongated shape.

\section{Drainage Density}

Drainage density of a stream has been recognised as fundamental characteristics of topography. It is defined as a measure of the texture of a drainage system, expressed as the ratio of the total length of all stream channels with a unit area.

Drainage density refers to total stream channels length per unit area (R.E.Horton,1945). It provides a better quantitative expression to the dissection and analysis of landforms, although function of climate, lithology and structures and relief history of the region etc. can be ultimately be used as an indirect indicator to explain those variables as well as for morphogenesis.

To find out the drainage density, the following formula is being used suggested by Horton i.e., $\mathrm{Dd}=\mathrm{Lu} / \mathrm{Au}$

$$
\text { Where, } \begin{aligned}
\mathrm{Dd} & =\text { drainage density } \\
\mathrm{Lu} & =\text { total length of stream in a basin } \\
\mathrm{Au} & =\text { total area of the basin }
\end{aligned}
$$

Table- 5.3 Showing Drainage density of Digaru River Basin

\begin{tabular}{|l|l|c|l|}
\hline Height (in m) & Area (in sq. km ) & Area (in \%) & Category \\
\hline$<5$ & 98.16 & 35.52 & Low drainage density \\
\hline $5-6$ & 71.26 & 25.13 & Moderate drainage density \\
\hline$>6$ & 111.12 & 39.34 & High drainage density \\
\hline
\end{tabular}




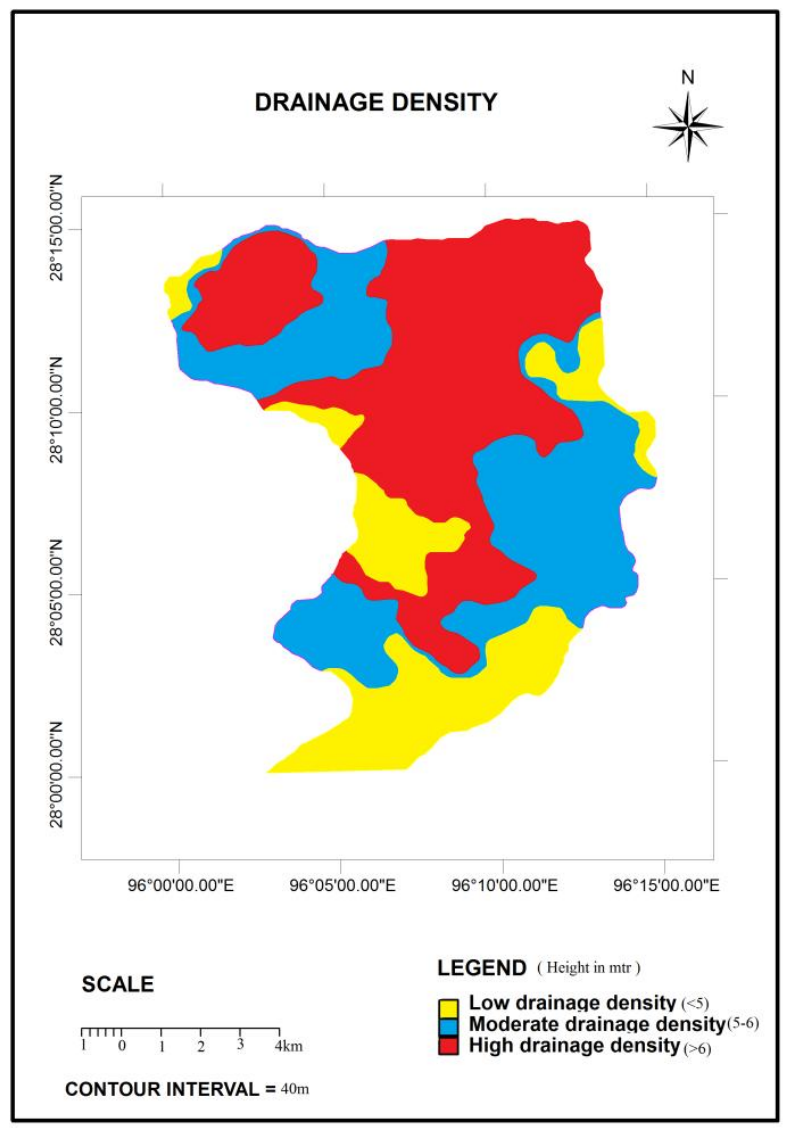

\subsubsection{Low drainage density}

Fig. 5. 3: DRAINAGE DENSITY MAP OF DIGARU RIVER BASIN

The table 5.3 shows that the drainage density of Digaru river basin ranges between 0.4 to $12 \mathrm{~cm}$. The low drainage density ranges from 0.4 to $5 \mathrm{~m}$ covering an area of about $98.16 \mathrm{sq}$. Km, which accounting $35.52 \%$ area of the total basin area. These vary category is scattered in the southern, western and northeastern portion of the basin.

\subsubsection{Medium drainage density}

The medium drainage density ranges between $5-6 \mathrm{~m}$, covering an area of about $71.26 \mathrm{sq}$. Km. It accounts $25.13 \%$ area of the total basin area and it is concentrated in the central and northwestern portion of the study area.

\subsubsection{High drainage density}

The more than $6 \mathrm{~m}$ range is termed as the high drainage density area. It covers an area of about 111.12 sq. Km, which accounts $39.34 \%$ of the total basin area. The high drainage density category is concentrated in the northern tip and the central region of the basin area.

In the concluding part, the result we found that with the increase in relief the drainage density increases. It is due to its lithological characteristics and off course the vegetation cover.

\section{Drainage Frequency}

Drainage frequency can be defined as the number of stream segments per unit area. It was Horton (1945), who first brought the concept of stream frequency which had been followed by Mellon (1958) and many other geo-scientists. Drainage frequency is calculated by dividing the total number of streams passing through each grid by the total unit area of the basin (area of grid). For the present study, the drainage frequency has been calculated by dividing the whole basin area into $2 \mathrm{~cm}^{2}$ grids and counting the total number of stream crossing in each grid. By using the Planimeter the area of grid has been measured and by computing the formula suggested by Horton (1945), the drainage frequency of the Digaru river basin is being calculated. The formula we used is-

$\mathrm{DF}=\mathrm{N} / \mathrm{A}$

Where, $\mathrm{DF}=$ drainage frequency

$\mathrm{N}=$ total number of stream crossing in each grid 
$\mathrm{A}=$ total unit area ( area of grid)

After evaluating the ratio, the calculated result is placed accordingly to their respective grids and suitable class interval is being made. The isopleth technique is being used. The table bearing no.5.4 below is being prepared to show the drainage frequency of the Digaru river basin considering the intervals:

Table- 5.4 Showing Drainage Frequency of Digaru River Basin

\begin{tabular}{|l|c|l|l|}
\hline Drainage frequency (in m) & Area (Sq. Km ) & Area (in \%) & Categories \\
\hline$<5$ & 74.65 & 25.95 & Low drainage density \\
\hline $5-7$ & 130.55 & 45.38 & Medium drainage density \\
\hline$>7$ & 82.45 & 28.66 & High drainage density \\
\hline
\end{tabular}

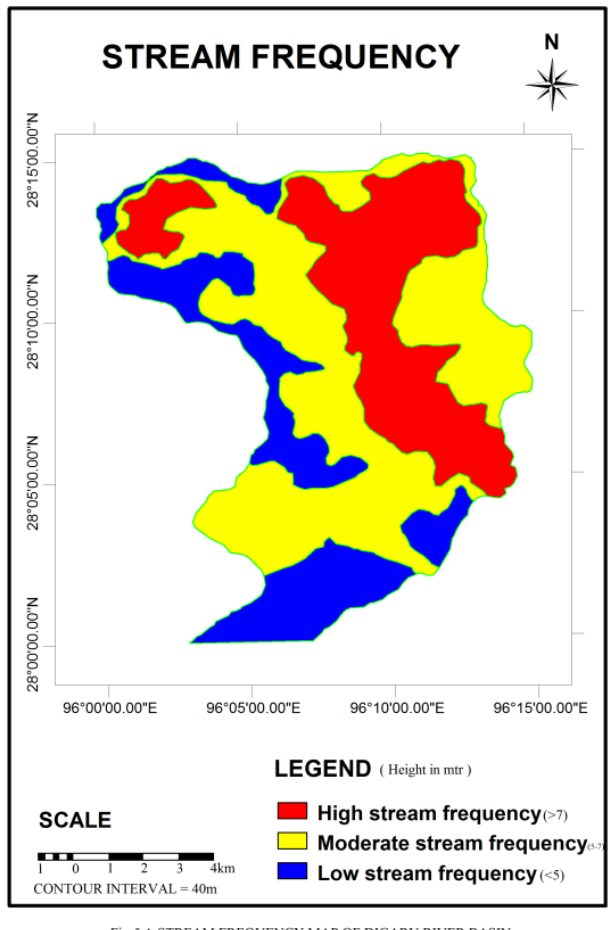

Fig 54: STREAM FREQUENCY MAP OF DIGARU RIVER BASIN

\subsubsection{Low drainage frequency}

The low drainage frequency covers an area of about 74.65 sq. Km, accounting $25.95 \%$ area of the total basin area. It is found in the southern and north-eastern portion of the basin.

\subsubsection{Medium drainage frequency}

It ranges between 5-7 m, covering an area of $130.55 \mathrm{~km}$ and accounting $45.38 \%$ area of the total basin area. The medium drainage frequency area scattered all over the basin.

\subsubsection{High drainage frequency}

The region lying above $7 \mathrm{~m}$ is named high drainage frequency. It covers an area of about $82.45 \mathrm{sq}$. $\mathrm{Km}$, accounting $28.66 \%$ area of the total basin area. It is concentrated in the central and northern portion of the basin.

\section{Longitudinal Profile}

The longitudinal course of a river from its source to mouth is called Longitudinal profile. It represents the channel gradient of the river from its source to mouth. The longitudinal channel course is generally a smooth curve, which rises upstream.

A river is supposed to ultimately remove topographic irregularities by penultimate stage and to develop smooth curve from source to mouth. The maximum limit of vertical erosion is determined by grand base level which represents sea level thus river always try to erode their valley down to base level of erosion near valley floor become concave curve of their channels. The concavity of a long profile of river results from the fact that there is minimum erosion in the middle segment.

Lack of required amount of erosion tools and water in the source segment and gentle gradient and very low flow in the lower segment of a river are responsible for minimum erosion where as sufficient load, channel 
gradient and flow velocity in the middle course of a river caused maximum erosion of a valley floor. This is why a river develops a smooth concave curve of longitudinal course.

When a river develops such course that channel gradient is such that resultant flow velocity is able to transport entire load, the resultant longitudinal curve of long profile is called graded curve and the river becomes profile of equilibrium as there is balance between transporting capacity of the river and total load to be transported i.e., balance between available energy and the work to done.

Long profile/valley thalweg gives a vivid picture of breaks in longitudinal course of the river and numerous pronounced breaks may indicate nick points or heads of rejuvenation, these breaks help in examining the polycyclic nature of landform development.

The longitudinal profile of Digaru river basin is shown below in the table and figure-

Table- 5.5 Showing Longitudinal Profile of Digaru River Basin

\begin{tabular}{|l|l|l|}
\hline Height & Length (in km) & Cumulative length (in km) \\
\hline$>3400$ & 0.4 & - \\
\hline $3200-3400$ & 0.7 & 1.1 \\
\hline $3000-3200$ & 0.25 & 1.35 \\
\hline $2800-3000$ & 0.35 & 1.7 \\
\hline $2600-2800$ & 0.3 & 2 \\
\hline $2400-2600$ & 0.275 & 2.27 \\
\hline $2200-2400$ & 0.25 & 2.52 \\
\hline $2000-2200$ & 0.35 & 2.87 \\
\hline $1800-2000$ & 0.4 & 3.27 \\
\hline $1600-1800$ & 0.125 & 3.4 \\
\hline $1400-1600$ & 0.275 & 3.67 \\
\hline $1200-1400$ & 0.725 & 4.4 \\
\hline $1000-1200$ & 0.375 & 4.77 \\
\hline $800-1000$ & 1.45 & 6.22 \\
\hline $600-800$ & 2.25 & 8.47 \\
\hline $400-600$ & 14.6 & 23.07 \\
\hline $200-400$ & 11.8 & 35.02 \\
\hline
\end{tabular}

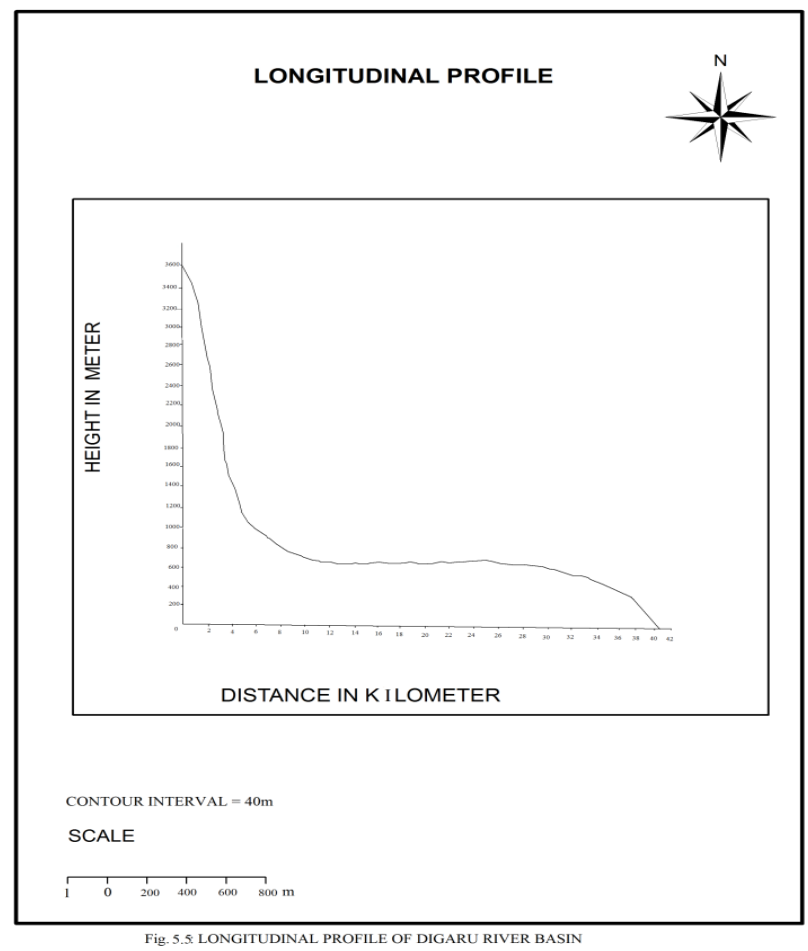

\section{Result Derived:}

From the present study, it had been found that the upper reaches of the Digaru river have high gradient and due to the variation in the gradient, structure ant lithology of the region,there is frequent changes in the values of gradient indices in the upper reaches. There are two prominent break points along the longitudinal profile of the Digaru river (Gradient Index values 23.07 and 35.02) suggesting two major orogenic movements 
in the area. The minor break points along the profile have developed either due to the changes in lithology or the presence of minor faults in the area.

\section{Conclusion}

The present study has brought out that the varied characteristic of drainage network is due to the geological and climatic condition of the study area. Thus the result obtained can be used in watershed management strategie. The morphology of an area is expressed by the appearance, dimension and magnitude of its slopoes and the relief express the amount of the slopes and the nature of the surface slope. Regional variation in slopes is associated with tectonic movement with high degree of denudational activities besides other factors such as weathering, erosional and transportational process etc., which have shaped the slope of the catchment area. The relative relief map expresses the nature of the surface slope of the catchment area. The surface with relative relief ranging from $700-900 \mathrm{~m}$ and above covers $20.76 \%$ area of the total basin area mostly concentrated in the northern and eastern portion showing a high dissected and undulating topography. Moderate relative relief ranges between $500-700 \mathrm{~m}$ covering area of about $34.51 \%$ of the total basin area is scattered in the central ant northern part of the basin. And the lowest relative relief occupies $16.55 \%$ of the area, which covers the whole eastern and lower portion of the basin upto the mouth.

Now, with this we can conclude that the analysis of morphometric parameters is very important in understanding the geological set up and the evolution of various topographical features due to fluvial processes on the earth surface.

\section{Bibliography}

[1]. Arunachal Pradesh at a Glance, 2010, Directorate of Economics and Statistics, Government of Arunachal Pradesh, Itanagar791113.

[2]. Bangsia, Watsen (2005). Geomorphological Analysis of Tissa River Basin, Arunachal Pradesh, M.A Dissertation report submitted to Department of Geography, Rajiv Gandhi University, Rono Hills Doimukh, Itanagar 791112.

[3]. Bassey Eze \& Efiong (2010). Morphometric Parameters of Calabar River Basin: Implication for Hydrologic Processes, Department of Geography \& Regional Planning, University of Calabar, Nigeria: Journal of Geography \& Geology, vol. 2, No. 1

[4]. Bloom, Arthur.L (2002). Geomorphology- A Systematic Analysis of Late Cenozoic Landform, third edition, Prentice Halls India Ltd, New Delhi 110001.

[5]. Chozum, Karma (2009). Morphometric Analysis of Sangti River Basin, West Kameng, Arunachal Pradesh, M.A. Dissertation report submitted to Department of Geography, Rajiv Gandhi University, Rono Hills Doimukh, Itanagar 791112.

[6]. Devi, E. Girja, et al. (2003). Longitudinal Profile Analysis of Leimatak River, Manipur, India, Arunachal University Research Journal, Rono Hills Doimukh, Itanagar, 791112, vol. 6 (1), pp. 65-73.

[7]. Devi, Hijan Ibeyaima (2000). River Basin Morphometry, M.L Gupta Rajesh Publications 1, Ansari Road, Darya Ganj, New Delhi110002

[8]. Gravelins (1914). Order of Streams

[9]. Indian Meteorological Department.

[10]. Leopold, B. Luna, et al. (1970). Fluvial processes in geomorphology, Eurasia Publishing House (pvt) Ltd, New Delhi-110001, 55.

[11]. Leopold.L.B \& Wolman.M.G (1957). Channel pattern, Channel Morphology: Geomorphology, Savindra Singh, Prayag Pustak Bhawan 20-A University Road Allahabad-211002. P. 406

[12]. Maarten.G.Kleinhans. (2010) Sorting out River Channel Patterns; vol. 34, 3: Pp 287-326

[13]. Morkhove.F.G \& Wilkinson.H.R (1967). Hypsometric Curve

[14]. Mosley.P \& Jowett.I (1999). River Morphology and Management in New Zealand, vol. 23, No. 4 : Pp 541-565

[15]. Riba, Jumri (2004). Geomorphic Analysis of Siji River Basin, Arunachal Pradesh, M.A Dissertation Report submitted to Department of Geography, Rajiv Gandhi University, Rono Hills, Itanagar 791112

[16]. Rupa, Tage (2007). A Geomorphological and Land use study of Kiile river basin, Eastern Himalaya, Arunachal Pradesh, Unpublished Ph.D thesis.

[17]. Sema, P.Toiho (2009). Slope Analysis of Zunheboto District: A geographical Analysis, Hill Geographer, the Geographical Society of North-Eastern Hill Region (India) Shillong-793022, vol XXV, no. 1\&2, pp. 71-75.

[18]. Sharma, S.H. (1991). Indian Geomorphology, Concept Publishing Company, A-15/16, Commercial Block, Mohan Garden, New Delhi-110059, pp- 137-200.

[19]. Singh, R.L. (1979). Elements of Practical Geography, Kalyani Publisher, 1/1, Rajendra Nagar, Ludhiana-141008, Bharat Road, Daryaganj, New Delhi-110002.

[20]. Singh, Savindra (2009). Geomorphology, Prayag Pustak Bhawan 20-A University Road Allahabad-211002, $353-384$.

[21]. Singh, Surendra (1999). A Resource Atlas of Arunachal Pradesh, North Eastern Hill University, Government of Arunachal Pradesh, Shillong-793014, p-13.

[22]. Statistical Handbook of Lohit District, 2010, District Statistical Office, Lohit District: Tezu-792001, Government of Arunachal Pradesh.

[23]. Taher M. and Ahmed.P. (2002). Geography of North East India, P.K.Dutta, Mani Manik Prakash Panbazar, Guwahati-781001, pp- 12-40, 41-53.

[24]. Vishwas.S.Kale (2002). Fluvial Geomorphology of Indian Rivers: An overview, vol. 26, 3 : Pp 400-433.

[25]. Wood.A. (1942). Types of Slope. Geomorphology, Savindra Singh, Prayag Pustak Bhawan 20-A University Road Allahabad211002, 268 